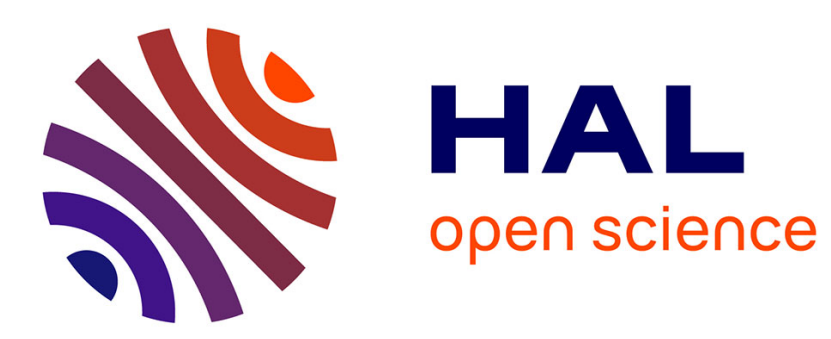

\title{
The reform of passenger rail in Switzerland: more performance without competition
}

\author{
Christian Desmaris
}

\section{To cite this version:}

Christian Desmaris. The reform of passenger rail in Switzerland: more performance without competition. Thredbo 13. 13th International Conference on Competition and Ownership in Land Passenger Transport, Sep 2013, Oxford, United Kingdom. halshs-00860911

\section{HAL Id: halshs-00860911 https://shs.hal.science/halshs-00860911}

Submitted on 11 Sep 2013

HAL is a multi-disciplinary open access archive for the deposit and dissemination of scientific research documents, whether they are published or not. The documents may come from teaching and research institutions in France or abroad, or from public or private research centers.
L'archive ouverte pluridisciplinaire HAL, est destinée au dépôt et à la diffusion de documents scientifiques de niveau recherche, publiés ou non, émanant des établissements d'enseignement et de recherche français ou étrangers, des laboratoires publics ou privés. 


\title{
The reform of passenger rail in Switzerland: more performance without competition
}

Thredbo 13 workshop 5 - The Roles and Responsibilities of Governments and Operators.

\author{
Christian Desmaris ${ }^{a}$ \\ a Corresponding and Presenting author: Institute of Political Studies of Lyon, Laboratory of Transport Economics (LET), \\ University of Lyon, 14 avenue Berthelot, 69365 Lyon, cedex 07, France. +33 (0)37283841. Email: \\ christian.desmaris@sciencespo-lyon.fr \\ Keywords: \\ Swiss railway reform \\ Regulation \\ Regionalization \\ Railway contracts \\ Passenger Rail \\ Transport policy
}

\section{ABSTRACT}

The Swiss railway system is known for its high quality of service and integration in a particularly dense public transport system. People are generally less aware of ongoing institutional reform. This article strives to shed light on passenger traffic reform, and more particularly on regional traffic. Which institutional frameworks are implicated? What have been the results obtained both for public finances and for travelers? What are the key elements for explaining recorded performance gains? What lessons could be drawn for railway reform? In sum, it appears that improved performance has been possible in Switzerland even in the absence of competition. These improvements are due to the nature of public governance and its impact on the various stakeholders. Public authorities have imposed ambitious but negotiated targets on operators, coupled with severe financial constraints, in a context of decentralization of public procurement. Given this new institutional framework, railway companies and especially the former monopoly holder, the incumbent SBB have achieved significant productivity increases through management and technical innovation. Client satisfaction, at the heart of the reform, also contributes to these successes.

\section{Introduction}

The quest for the optimal railway system continues (I. Kessides and Willig, 1995; ECMT, 1998, 2007; Nash, 2011; CER, 2012; Crozet and al., 2012). This is shown by the European Commission's regulatory hesitations, the most recent enactment happening at the end of January, 2013, with the announcement of a fourth railway package, to be implemented from December, 2019, liberalizing the market for domestic passenger transport services by rail and fully separating infrastructure and operation management (COM2013/25/EC). This paper aims to describe the institutional changes taking place in the Swiss passenger rail transport system and to highlight the consequences for stakeholders and on performance. Paradoxically, very little research has been devoted to this subject (Van de Velde, 1999; Maier-Gyomlay, 2013).

And yet these reforms have significantly improved performance in Switzerland, both in terms of the cost to taxpayers and the quality of service provided to passengers. These successes 
raise many issues. What is the institutional nature of these reforms? What are the results? How have these successes been leveraged? What can be learned from Switzerland's example? Such are the questions we will attempt to answer in this paper.

\section{Historical overview of Swiss railway reform: governance vs. competition}

Swiss railway reform may be divided into three stages: in 1996 the "Revision of the federal law on railways" (Railways Act), which could be considered part of a "regionalization" process; in 1999 the "Railway Reform 1", with broader scope and, from 2005, the "Railway Reform 2", still partially under debate and implementation (CER, 2011).

\subsection{The first stage - 1996: regional traffic reform}

The Swiss railway reform began with a redefinition of the principles governing regional passenger transport. ${ }^{1}$ Thus in Switzerland, railway reform began with regional reorganization. Legislation was launched with the Railways Act of March 24th, 1995, which entered into force on the 1st of January, 1996. This legislation was based on three principles transforming relations between rail companies and public administration (Genoud, 2000).

The most significant change is known in Switzerland as the "ordering principle", and corresponds to the implementation of a "net cost" contract. Public authorities only pay for services agreed upon in advance (for a given route, for an established duration, providing for specific services) and only pay the amount clearly stated in the contract. The amount of any financial compensation corresponds solely to the running loss projected by the operator period initially. This type of contract incites the commissioned operator to both reduce costs and increase income, as any losses will not be covered ex post.

The second change is in the powers transferred to canton authorities. Formerly, the Confederation and the SBB set the basic conditions for regional commuter transport and met all expenses. The only position for cantons consisted in presenting their scheduling requirements, thus one of simple "supplicants" (Blumenthal, 1998). The new reform held the cantons entirely responsible for organizing regional commuter services in their respective territories. Nonetheless, discretionary powers remained with the Federal Office of Transport (FOT). The latter remained guarantor of traffic coordination at the national level, was cosignatory to all contracts and directly paid operators all pre-agreed financial compensation.

The third innovation in the railway reform lay in the end of the SBB monopoly for regional railway services. This was undoubtedly the most innovative of the clauses, and opened up competition for regional transport commissions to multiple operators. Thus far, however, there has never been competition for local or regional railway transport. The canton authorities do not publish bids for tender and there are no foreign service providers on the market (Finger and Genoud, 2004; Finger and Rosa, 2012). This is not the case for local and regional road transport, where public procurement tenders are now mandatory.

To be complete, this first stage in Swiss reform needed to be coupled with transforming the SBB into a structure with truly independent management. This was the object of the second railway reform.

\footnotetext{
${ }^{1}$ By regional passenger transport we refer to local passenger commuting services commissioned by the cantons and provided by the Swiss Federal Railways (SBB) or other so-called "private" companies owned in majority by the cantons. National transport is commissioned by the Confederation; it is currently provided by the SBB.
} 


\subsection{The second stage - 1999: a new regulatory framework in keeping with European legislation}

An additional stage in the process of railway reform was enacted with the "Railway reform 1" (Railways Act, dated 20th March, 1998) applicable from 1st January 1999. The main goal was to transpose into national law the principles laid out in Directive 91/440/CEE. This reform had the effect of separating transport activities from infrastructure management. It also liberalized access to the railway for all authorized parties (essential for "on the market" competition, already in effect for freight in Switzerland). Lastly, it significantly overhauled the organization and business model of the SBB.

One of the main goals of this rail reform was to end the authority of the federal administration over the SBB. Although it remains the exclusive property of the Confederation, in the form of a public limited company, the SBB gained true operating autonomy, becoming independent from political and administrative power, subject to them only through a multi annual contract. In this contract the Confederation establishes the SBB's strategic orientations for a four year period: its operational targets, its orders for expected passenger rail and freight services, requirements in railway infrastructure, and the amount of public compensation. When this change in status was decided, the Confederation also decided to erase all SBB debts (NERA, 2004). Lastly, this reform also led to a reorganization in activities, which were divided into four distinct branches: Passenger traffic, Cargo, Infrastructure and Real estate. In keeping with European regulations, the SBB also implemented separate accounting and an organic separation between rail infrastructure and operation. All in all, these new provisions have made a fresh start possible for the SBB in the European rail sector, currently undergoing liberalization.

SBB reform has also had a significant impact on sector regulations, and more particularly on the nature of the tasks confided to the Federal Office of Transport. So-called "sovereign" missions of the SBB, conflicting with its new status of rail company, were therefore transferred to the FOT.

\subsection{Since 2005, Railways Reform 2: controversial and incomplete}

In 2005 the government presented a new railway package to Parliament, the "Railway Reform 2". The main goal was to transpose into Swiss law the First and Second EU Railway packages. These legislative packages laid out various measures on multiple subjects, such as how to finance rail infrastructure, how to establish regulatory authorities capable of fairly allocating railway slots to all rail companies, on safety in public transport. Parliament rejected the legislative package and suggested that the government divide it over several more narrowly focused bills (CER, 2011). The government then attempted to introduce the Railway 2 reform in installments.

The first part of this reform, related to railway regulation, safety and commission length in regional transport (from one to two years in duration), entered into force in 2010. This reform included inter alia the Passenger Transport Act dated March 20th, 2009 (French acronym "LTV"). It was supplemented by the ordinance on compensation for regional passenger transport dated November 11th, 2009 (French acronym "OIRTV"). The second part of the Railway Reform 2, submitted to public consultation in 2009, was presented before the Parliament beginning in 2011 (Finger and Rosa, 2012).

It is highly interesting to note that three items in this new phase of Swiss rail reform are particularly controversial: 1 ) the importance awarded to the tendering principle in attributing 
passenger rail transport; 2) the rules pertaining to infrastructure financing, particularly those establishing the portions covered by the Confederation and the cantons respectively; 3) the choice of optimal architecture for infrastructure management (Litra, 2008). The Swiss rail system is globally integrated, like its Japanese model. The fact that Switzerland has a single rail system is often put forward as an essential condition of its exceptional performance (Meier and Meyer, 2011).

Generally speaking, changes in railway legislation in Switzerland show pragmatic reforms, step by step, with at least four objectives: to integrate Switzerland in the new European rail landscape; to improve rail transport efficiency by significantly increasing operating productivity and profitability as well as the quality of services provided; to overcome challenges posed by increasing mobility, namely by increasing the share covered by rail and lastly, to improve the cost/benefit ratio of public subsidies.

While the principle of competition is accepted, for both international freight and passenger rail, one can but observe that for domestic traffic (regional and national), the "Swiss model" differs from the standards being promoted by the European Commission, based on market liberalization and competition between operators. Institutionally it has its own specificities and is more akin to a particular type of governance implicating public authorities, rail companies (and public transport companies more broadly) and travelers, than to a true change in its market structure, based on more open competition.

\section{Rail reform fruitful for both taxpayers and travelers}

Swiss rail reform of regional passenger transport had two positive outcomes: more efficiency in the use of public money and better and more services provided to passengers.

\subsection{More efficient use of public funds}

The most spectacular result, a driving force behind the reform, has been the inversion of the trend whereby public compensation contributions steadily rose for regional traffic (Table 1 ). The SBB have managed, with a globally constant volume of public funding, to regularly increase both the number of kilometers on offer and passenger traffic. ${ }^{2}$

Whereas in the beginning of the 1990s non covered costs for regional traffic were rising strongly, amounting to CHF 560 million in 1990, and CHF 725 million in 1993, from 1997 the public compensation disbursed by the Confederation for regional traffic decreased in nominal value, and therefore even more in real value. Since 2003 it has risen slightly in nominal value, without however upsetting the clear improvements in public fund use efficiency. For each train-kilometer provided, the Swiss government paid CHF 10.2 in 2000, and only CHF 7.6 in 2006 (as in 2010), with a slight increase in 2011, at CHF 7.7. Thus improvements in the efficiency of public compensation paid to the SBB for regional rail transport are spectacular, more than 25\% since 2000 (Table 1).

The exemplary nature of this performance is all the more striking if one compares it to the situation in France, which undertook rail regionalization during the same period. In France, public contributions for the operation of regional passenger services have consistently risen,

\footnotetext{
${ }^{2}$ If one examines all public funding (with the exception of major infrastructure projects) spent on rail since the reform, one notes a triple trend characteristic of Swiss governance: 1) near stable public contributions of approximately CHF 3 billion (in fact CHF 350 million between 1995 and 2010); 2) a very strong increase in contributions for investment in the network, rising from circa CHF 200 million in 1995 to 1.5 bn in 2010; 3) a notable decrease in current contributions, both in terms of traffic compensation and of infrastructure operation (CHF -950 million between 1995 and 2010, totaling CHF 1.68 bn in 2010).
} 
from EUR 1.405 tn in 2002 to 2.572 th in 2011 (+83\% in current value). In terms of trainkilometers, they cost French taxpayers EUR 9.45 in 2002 and EUR 15.2 in 2011, i.e. an increase of more than 60\% (Crozet and Desmaris, 2011).

Table 1 Public compensation contributions paid to the SBB for regional passenger transport

\begin{tabular}{|r|r|r|r|r|r|r|r|r|}
\hline & 1993 & 2000 & 2002 & 2004 & 2006 & 2008 & 2010 & 2011 \\
\hline Regional contributions & & & & & & & & \\
\hline In millions of current value CHF & 725 & 546 & 507 & 522 & 552 & 571 & 556 & 577 \\
\hline Index, basis 100 in 2000 & -100.0 & 92.9 & 95.7 & 101.2 & 104.6 & 101.9 & 105.4 \\
\hline Regional contributions I train-km & & & & & & & & \\
\hline In current value CHF & N.A. & 10.2 & 8.9 & 8.1 & 7.6 & 8.1 & 7.6 & 7.7 \\
\hline Index, basis 100 in 2002 & N.A. & 111.7 & 100.0 & 91.2 & 85.4 & 90.8 & 85.5 & 86.6 \\
\hline
\end{tabular}

Source: Our calculations, based on several SBB Management reports.

\subsection{Higher quality services for rail passengers}

The second result of the rail reform, which is particularly enviable, is the significant improvement in the quality of services for passenger rail. Switzerland is traditionally known for the excellence of its railway (Bovy, 1992). Intermodality has reached unsurpassed levels, linking together all constituent parts of the Swiss public transport network (Bovy, 1994; UTP, 2008). Service frequency is the highest in the world, setting Switzerland ahead of Japan, with over 94 trains daily per line (as compared to 47 in Germany, 40 in the U.K. and only 30 in France - Litra, 2008). Train punctuality is stable with exceptionally high rates, nearly $90 \%$ in 2011 (percentage of passengers either arriving on time or less than 3 minutes late), with a successful connection rate of nearly $97 \%$ (SBB, 2012a).

The reform of the railways has led to two other satisfying results for travelers: increased commercial speed and more trains.

The effectiveness of railway passenger transport expressed in terms of time savings has increased: Average train speed has risen substantially, i.e. by more than $23 \%$, from less than $50 \mathrm{~km} /$ hour on average in 1994 to over $61 \mathrm{~km} /$ hour in 2010, according to the microcensus data (OFS, 2012). Car travel speeds remain well below, around $37-38 \mathrm{~km} /$ hour, showing almost no progress. The bulk of speed improvements took place between 1994 and 2005 , following implementation of the broad investment and modernization program called "Rail 2000" (Carron, 2004; Weibel, 2012). Rail 2000 significantly improved the attractiveness of passenger rail by increasing train frequency (15 minutes on the busiest routes, 30 minutes on all others) and by systematically taking into account correspondences between rail and other modes of transport (Torrego and Graffagnino, 2012). Improved rail transport performance has had another beneficial effect, more travel by train rather than by car. Whereas the daily average distance traveled by train was $4.2 \mathrm{~km}$ in 1994, it was $7.1 \mathrm{~km}$ in 2010 , an increase of $67 \%$ (as compared to $12 \%$ for car travel). ${ }^{3}$

\footnotetext{
${ }^{3}$ The method used by the Swiss micro-census differs from that of the UIC. The micro-census methodology divides the average domestic mileage per capita traveled by train by the 365 days of the year. For the UIC,
} 
The final but important factor in quality improvement is the increased supply of services. Measured in train-kilometers, the total SBB supply for travelers shows considerable increase, $50.5 \%$ since the reform. The volume of train-kilometers was 90.3 million in 1995 and rose to 136 million in 2011. The increase in kilometers offered was much more gradual before the reform, at 35\% between 1980 and 1995. This increase in supply applies both to national and regional traffic. For regional transport alone (including by bus), the number of kilometers on offer increased from 51.4 million train-km to 76.9 million between 2000 and 2011, an increase of $49.6 \%$ in total or a yearly average increase of 3.7\% (SBB, 2012a).

\section{The levers of success: a 'win-win' situation designed by public authorities}

We believe the performance gains obtained by Swiss rail should mainly be ascribed to the nature of their public governance which tends to bring together all stakeholders in the rail system, i.e. public authorities, rail operators and consumers.

\subsection{The first key to success: public governance promoting sustainable mobility centered on the railway system}

The main reason for the success of Swiss rail reform lies in its particular form of public governance which aims to promote sustainable mobility based on train travel. Let us look in more detail at three characteristics.

\subsubsection{A collective choice to foster rail transport based on a high level of infrastructure investment}

Switzerland is noteworthy in its maintained and updated national choice in favor of rail transport, which translates into sustained high levels of investment (ECMT, 1999; Keseljevic and Meillasson, 2001; Carron, 2004). Initially, Switzerland promoted travel by road, but from the 1990s changed its policy in favor of rail. Following intense public debate and consultations, a major modernization program for rail was adopted in 1998. The program had a budget of over CHF 30 billion for a twenty year period and was dubbed GPF ("grands projets ferroviaires", i.e. major rail projects). It made complete modernization of passenger rail its priority, placing the sector at the center of its public transport network. For greener freight transport in Switzerland it also included an ambitious program for new Alpine train lines, the NLFA (OECD, 2006).

Two figures illustrate the clear priority granted since then to Swiss rail transport. En 2009, the federal government invested CHF 4.5 billion in roads and CHF 3.8 billion in rail (Litra, 2012). In 1990, the proportion was CHF 3.7 for roads and only 2 billion for rail. This collective choice can also be considered in terms of per capita rail investment: CHF 82 in 1980, CHF 291 in 1990, CHF 405 in 2000 and CHF 489 in 2009, i.e. an almost six-fold increase in currant values in under 30 years.

\subsubsection{Local authorities are increasingly implicated in decision-making and funding}

The Swiss rail reform included a process of decentralization which is manifested in two ways: the cantons have full responsibility over decisions with respect to services provided, including offer consistency, and, in return, these services are funded by local public funds. The contract is freely negotiated between the two parties, namely the canton and the railway company. In practice, the railway company submits an offer to the canton for the public

average rail distance is calculated as a ratio between the number of passenger-kilometers and the number of passengers carried. It amounted to $49.5 \mathrm{~km}$ in Switzerland in 2010. 
services requested. Although the amount of financial compensation is freely negotiated between the parties, the contract must nonetheless be approved by the Federal Office of Transport (Weibel, 2005).

Since 2004, the financial relations between the Confederation and the cantons are governed by new rules, the new fiscal equalization rule (NPF in French). This financial framework has made it more difficult to access federal funds and limited the share contributed by the Confederation to financing regional passenger traffic (Art. 6 of the OIRTV of 11 November 2009). The Confederation's share, which in 2003 still represented, on a national average, $65 \%$ of the contributions made towards regional traffic (OFS, 2004), has now reached the level of $50 \%$, as stipulated in the Act (OFS, 2011). At the end of 2010, the Federal Council attempted to further reduce its share, by proposing to increase the minimum traffic threshold granting access to compensation for regional transport, from 32 to 100 passengers per line and per day. An agreement was reached in the end, establishing a minimum threshold for covering costs in terms of the revenue levels governing the Confederation's financial participation. Currently this threshold is set at $20 \%$ (Art. 4 of the TRV Directive of 10 December 2010).

\subsubsection{SBB corporate governance to enhance motivation and increase accountability}

The profound changes in relations between the SBB and their shareholder, the Confederation, seems to be a too seldom mentioned key factor in the successes achieved by Swiss rail reform (Peschelt, 2010). Two aspects of SBB governance by Swiss public authorities deserve to be highlighted: the setting of clear, precise, demanding and strictly controlled strategic objectives as well as mandatory adherence to drastic financial constraints on the part of the railway operator.

The first aspect of this corporate governance consists in genuine strategic guidance for the national railway company by its shareholder. The SBB's activities are carried out within the framework of a four-year contract, called the "Service agreement". One notes the very high level of service demanded by the shareholder of the incumbent operator in terms of constant improvement in the quality of services and in terms of efficiency gains in the use of public funds. There are specific objectives for customer satisfaction, punctuality and safety and, more generally, for a high level of service, as well as for productivity gains. Satisfactory financial results are also demanded, for each sector of activity, in order to provide a sound basis for the entire company and balanced results in the medium term. Moreover, the convention includes a ceiling for public contributions, for both infrastructure and operating services. Inversely, it is worth noting the constancy of the public authorities in Switzerland: the financial commitments to the SBB having been very widely honored since the reform. This observation is in keeping with another factor noted by E. Calthrop (Weibel, 2005), i.e. the exceptional stability of the leaders in charge, within both the Department of Transport and SBB management. Another striking factor is the detail of periodic reporting (monthly and yearly) stipulated in the Agreement, based on a host of indicators which may be based on value-thresholds considered as objectives. The SBB annual management report is a model of its kind, precise, comprehensive, argumentative and, seemingly, honest.

The second element in this original form of corporate governance, initiated by public authorities, is the absolute financial constraints imposed on the SBB. The Confederation's explicit strategy, to which it has stayed true, Agreement after Agreement, is to maintain the real value of the public funds allocated to the SBB at a stable level, while increasing 
demands in terms of targets to be reached (Table 2). The logic clearly being followed is to "do more with less".

Table 2 Changes in the expenditure ceiling for the SBB

\begin{tabular}{|c|c|c|c|}
\hline $\begin{array}{c}\text { Agreements on services } \\
\text { provided }\end{array}$ & $\begin{array}{c}\text { Overall amount (in } \\
\text { millions of current } \\
\text { CHF) }\end{array}$ & $\begin{array}{c}\text { Yearly average (in } \\
\text { millions of current } \\
\text { CHF) }\end{array}$ & $\begin{array}{c}\text { Base 100, yearly } \\
\text { average 1999-2002 }\end{array}$ \\
\hline $1999-2002$ & 5,840 & 1,460 & 100.0 \\
\hline $2003-2007$ & $6,020(5,602)(\mathrm{a})$ & $1,505(1,400)(\mathrm{a})$ & 103.1 \\
\hline $2007-2010$ & 5,880 & 1,470 & 100.7 \\
\hline $2011-2012$ & 3,322 & 1,661 & 113.8 \\
\hline $2013-2016$ & 6,624 & 1,656 & 113.4 \\
\hline
\end{tabular}

Source: Litra (2011a), Doku; Convention sur les prestations entre la Confédération et les CFF 2011-2012 et $2013-$ 2016

(a) After reductions due to spending cut-backs.

For regional transport, we noted above how the reform, because based on net cost contracts, was able to obtain level public funding costs and even considerable efficiency gains (Table 1). Following the reform, long distance traffic was also to be financially self-sufficient. Revenue generated by exclusive rights granted by the public authorities having to suffice to cover the railway operating costs for this particular traffic.

Given this ever more demanding fiscal framework, the SBB have had to implement drastic cost-cutting measures and to scout out all possibilities for new revenues. This priority has been strengthened by increasing demands by the Confederation for additional services and the absolute priority of maintaining infrastructure quality.

\subsection{The second key to success: an incumbent operator capable of considerable productivity gains and sweeping innovations in organization}

Swiss rail reform rapidly led to an upheaval in the purposes and tasks of SBB management. Beyond the change in legal status, which instated broader autonomy and accountability, the reform also instated a strategic reorientation around two main goals: to ensure that operators do their utmost to obtain productive efficiency and to take account of customers in all activities (Genoud, 2000). The explicit aims are to systematically keep operating and production costs down and to seek new revenues wherever possible.

\subsubsection{To seek and find significant productivity gains}

The SBB must grow while reducing costs. This two-fold message has been fully taken on board by the SBB in its operations since the reform. Measured in terms of apparent labor productivity, the gains are considerable: a two-fold increase between 1995 and 2010, slightly impeded by the impact of the crisis on traffic, freight in particular (Table 3). This sharp productivity rise breaks with earlier trends; since the reform average annual growth in labor productivity in the SBB is at $4.3 \%$ whereas, although there was growth before, it barely reached 2.1 per cent between 1980 and 1995. These productive efficiency gains are all the more remarkable as in Switzerland, contrary to many other European railways (Desmaris, 2010) they are based more on sensible increase in passenger and freight rail than on staff 
reductions (respectively, +51.6 per cent and +51.4 per cent as compared to $-22.9 \%$, between 1995 and 2011) (Table 3).

A comparative analysis, based on a sample of six major European rail companies, ${ }^{4}$ shows that this productivity spike is placing the SBB among the most productive European companies. Although in the 1970 s and 1980s, the SBB were among the European rail companies with the highest levels of labor productivity, others gradually caught up, and even sometimes surpassed them (Friebel and al., 2003).

Table 3 Changes in SBB traffic, staffing and productivity

\begin{tabular}{|c|c|c|c|c|c|c|c|c|}
\hline & \multirow[b]{2}{*}{1980} & \multirow[b]{2}{*}{1995} & \multirow[b]{2}{*}{2000} & \multirow[b]{2}{*}{2005} & \multirow[b]{2}{*}{2010} & \multirow[b]{2}{*}{2011} & \multicolumn{2}{|c|}{ Variation in \% } \\
\hline & & & & & & & $\begin{array}{l}1980- \\
1995\end{array}$ & $\begin{array}{l}1995- \\
2011\end{array}$ \\
\hline $\begin{array}{l}\text { Passenger-km in } \\
\text { millions (1) }\end{array}$ & 9,167 & 11,712 & 12,835 & 13,830 & 17,513 & 17,749 & +27.8 & +51.6 \\
\hline Ton-km in millions (2) & 7,220 & 8,156 & 10,658 & 8,571 & 13,111 & 12,346 & +13.0 & +51.4 \\
\hline Staff (3) & 38,367 & 33,529 & 28,272 & 25,943 & 25,356 & 25,840 & -12.6 & -22.9 \\
\hline $\begin{array}{l}\text { Labor productivity - } \\
\text { million traffic units (4) }\end{array}$ & 0.43 & 0.59 & 0.83 & 0.86 & 1.21 & 1.16 & +38.7 & +96.6 \\
\hline
\end{tabular}

Source: Our calculations based on Historical statistics of railways 1970-2009 (UIC, 2010), International Statistics Railways 2010 (UIC, 2011) and SBB (2012a).

NB. $(4)=(1)+(2) /(3)$. Based on the hypothesis that a passenger-kilometer is equivalent to a ton-kilometer.

This upward trend in labor productivity is not due to chance. It is the result of systematic policy on the part of the SBB committed to efficiency and productivity in all sectors, in order to meet the funding constraints and objectives imposed by the Confederation, its shareholder. This trend continues, and is part of a comprehensive policy for controlling operational costs, one that is constantly reaffirmed and renewed.

In passenger transport, cost reductions have been obtained in several ways, including by foregoing on-board ticket controls, a decision introduced in 1994 and fully implemented from June 1996 (Blumenthal, 1998). Some small stations or stops have also been closed or had their opening hours reduced.

To face increasing scarcity of federal subsidies for regional traffic, the SBB have also responded by deploying a partnership strategy with private railway companies well established at the local level. Redundancies in maintenance, marketing, management and sales have been reduced, resulting in an increase in productivity without adverse effects on service performance.

\subsubsection{To increase railway company revenues}

The second goal in managerial changes, to be realized through the railway reform, was to put customers at the center of SBB's activities. This win-win strategy aims to both improve quality of service and increase revenues for the railway company. The strategy has been successful.

\footnotetext{
${ }^{4}$ Our calculations from the UIC data on a sample of 6 countries: Germany, Spain, France, Italy, the United Kingdom, and Switzerland. On the basis of apparent labor productivity, the SBB ranked first in 1970, 1980 and 1985, third in 1995, and second after the RENFE in 2010.
} 
SBB operating accounts over ten years confirm that the strategy has increased revenues (SBB, 2012a). Thus between the fiscal years 2002 and 2011, although passenger traffic revenues increased by $52 \%$, public financial contributions to the SBB only increased by $20 \%$. In total over this period, operating revenues increased by $26 \%$, well above the increase in operating costs, i.e. $22 \%$ (with only an $18 \%$ rise in payroll costs). The result is an improvement in operating results, which rose from CHF 194 million in 2002 to CHF 530 million (in current value) in 2011.

We believe another factor has been particularly instrumental in allowing the SBB to be so successful in increasing revenues: the use of its real estate holdings in the vicinity of train stations. The SBB group is in fact one of the major real estate holders in Switzerland with 800 stations, 3,500 buildings, 4,000 plots, with a book value of nearly 4 billion Swiss francs, and an annual turnover of more than 600 million francs in 2011. In 2003, the SBB separated its real estate holdings from infrastructure, creating an independent business unit within the SBB. This business unit is used for development and now provides an essential contribution not only to the success of the integrated mobility policy and services offered to the SBB's clients, but also to the overall financial health of the railway company (Table 4). Real Estate is the most profitable of the SBB's activities, far ahead of transport, for any given year. In 2011, the SBB's rail activities (Passenger and Cargo) generated a profit of only CHF 168.0 million as compared to CHF 182.5 million from Real estate (Table 4).

The SBB's balance sheets do not reflect the true strategic importance of Real estate because of double internal levies on this branch (Table 4). Each year, profits realized by "Real Estate" are used first to repay a loan granted by the Confederation for balancing the SBB pension fund and second, to finance the infrastructure branch (totaling, respectively, CHF 182.5 and CHF 150.0 million in 2011).

Table 4 SBB group results by sector of activity (in millions of CHF)

\begin{tabular}{|c|c|c|c|c|c|c|c|}
\hline & 2002 & 2003 & 2004 & 2005 & 2006 & 2008 & 2011 \\
\hline Passenger traffic & 113.7 & 93.4 & 152.2 & 78.6 & 193.7 & 276.8 & 213.9 \\
\hline Freight traffic & -96.1 & -33.1 & -2.8 & -165.7 & -37.3 & -29.9 & -45.9 \\
\hline Infrastructure & 106.5 & 0.3 & 43.7 & 17.4 & 91.8 & 30.4 & 72.4 \\
\hline Real Estate (a) & - & -4.6 & 15.2 & 21.0 & 27.8 & 3.3 & 2.4 \\
\hline $\begin{array}{r}\text { Real Estate before } \\
\text { compensation payment (b) }\end{array}$ & - & 152.1 & 184.6 & 219.6 & 229.8 & 291.6 & 182.5 \\
\hline Central Units & -136.4 & -34.3 & -164.2 & -123.2 & -20.5 & 68.8 & 96 \\
\hline Intercompany transfers & - & 3.2 & -1.4 & 5.6 & 4.0 & -4.6 & 0.0 \\
\hline Group profit & -12.0 & 24.9 & 42.6 & -166.3 & 259.4 & 345.0 & 338.7 \\
\hline
\end{tabular}

Source: Our calculations based on various SBB Management reports.

(a) After interest and reimbursement payments on the loan granted for balancing the SBB pension fund and compensatory payments for Infrastructure.

(b) Added by us for comparison. Not to be taken into account in calculating the total of the "Group profit" Table. 
Thus, in challenging circumstances, the SBB proved themselves to be proactive, innovative and efficient. They have managed to master changes in their production costs, particularly by spectacular gains in labor productivity. They have also been able to boost and diversify their sources of income, both in rail transport and in their management of real estate, modeled on the Japanese style, centered on the possibilities provided by train stations. By this dual strategy, the SBB have become a profitable company, one of the major achievements of the reform.

\subsection{The third key to success: the support of consumers and citizens}

After sixty years of continual increase in the use of private automobiles, public transport has been gaining ground for the past ten years, in large part because of the market shares in passenger travel won by the railways.

\subsubsection{Exceptionally stable increases in passenger traffic}

The railway reform, and notably regionalization, marked the start of renewed affections between the Swiss and their railways. With the reform, the increase in the number of passengers carried by the SBB accelerated sharply, as did that that of passenger-kilometers (Table 5).

Table 5 SBB passenger traffic

\begin{tabular}{|c|c|c|c|c|c|}
\hline & 1980 & 1995 & 2011 & $\begin{array}{c}\text { Variation (\%) } \\
1980-1995(\mathrm{a})\end{array}$ & $\begin{array}{c}\text { Variation (\%) } \\
1995-2011(\mathrm{a})\end{array}$ \\
\hline Passenger-km in billions & 9.2 & 11.7 & 17.7 & $+27.2(+1.5)$ & $+51.3(+2.6)$ \\
\hline Travelers in millions & 216.3 & 253.2 & 356.6 & $+17.1(+1.0)$ & $+40.8(+2.2)$ \\
\hline Train-km in billions & 66.9 & 90.4 & 136.0 & $+35.1(+1.9)$ & $+50.4(+2.6)$ \\
\hline
\end{tabular}

Source: Our calculations based on Historical statistics of railways 1970-2009 (UIC, 2010) and UIC (2011).

(a) In parentheses, average rate of annual change.

Rail 2000 is a true success (Leuenberg, 2010; Finger and Rosa, 2012; Weibel, 2012). Regional traffic has followed the same trends as Swiss traffic globally and has maintained its market share of $25 \%$ of all SBB traffic expressed in passenger-kilometers. The modal share of public transport, after having declined steadily since the 1950s underwent a revival in Switzerland: from a minimum of $21.1 \%$ in 2000 it rose to $25.5 \%$ in 2010 . Two-thirds of these gains are to be ascribed to an increase in the use of rail. Its modal share, calculated in terms of passenger numbers, has increased from 11.1 per cent in 2000 to 13.9 per cent (Litra, 2012).

This upward trend in passenger traffic is in fact the highest in Europe after the United Kingdom, although Switzerland was already, by far, the world's most train friendly country. ${ }^{5}$ In 2010, with an average of 2,258 km per capita, Switzerland is ahead even of Japan, the other country known for its railway excellence $(1,910 \mathrm{~km})$, and far ahead of France $(1,320$ $\mathrm{km})$, Germany $(961 \mathrm{~km})$ and the United Kingdom (887 km) (Litra, 2011b). Moreover,

\footnotetext{
${ }^{5}$ Such record rail mobility can be ascribed to several favorable factors due to geography, history and policy. Geography, because of its mountains which lead to high population densities in valleys, but also because of a network of medium-sized cities connected by high levels of regional traffic. History, since Switzerland has been spared by the major wars, and thus has been able to retain its railway heritage. Policy finally, due to a strong environmentalist movement.
} 
Switzerland has reinforced its position as a leader in the use of rail, since at the beginning of the reforms, the Swiss "only" traveled $1,670 \mathrm{~km}$ by train each year. No other country has seen such progress. This result is all the more remarkable in that in Switzerland, contrary to France where the bulk of travel is long distance (by high speed train, 'TGV'), the high levels of traffic are mostly due to the frequent use of trains, over short distances. Thus whereas in Switzerland the yearly per capita average is 50 train trips, it is 24 in Germany, 22 in the United Kingdom, and 17 in France (Litra, 2011b).

\subsubsection{Traveler satisfaction and citizen support}

The satisfaction expressed by travelers and citizen support for the rail reforms carried out by the Confederation are important elements in their success.

Let us first note that passenger satisfaction has always been one of the main targets of the Swiss rail reform. The SBB have also made client satisfaction one of the primary criteria for the success of their business (SBB, 2012b) and state so very clearly. Customer satisfaction is regularly monitored through a multi-criteria survey of a broad sample of travelers (SBB, 2012b). Customer satisfaction was already high before the reform, and increased overall so that today it is at approximately $75 \%$ (SBB, 2012b). However, given the sustained growth in traffic and resulting saturation peaks, coupled with the drastic savings imposed by the Confederation on the incumbent railway operator, it will be a true challenge to maintain satisfaction at its current level.

Another relevant indicator of customer satisfaction is loyalty. Due to strong pressure from the federal Council to promote the use of trains, the SBB have implemented a price policy which favors ticket subscriptions. Thus, starting in 1987, the cost of half-price passes was sharply reduced (from CHF 360 to CHF 100). This resulted in a dramatic increase in the number of subscribers: 660,000 in 1984, just over 2 million in 1987 and 2.3 million in 2011 (SBB, 2012a). With this proactive policy, the number of general subscriptions rose even more sharply: with only 25,000 subscribers in 1990 to over 430,000 in 2011. Currently, 2.8 million Swiss have an SBB pass (out of the 6.3 million inhabitants over 20 years of age).

Lastly, one must also mention the deep commitment the Swiss express towards their railway system and the policies carried out on their behalf. Each of the major stages in Swiss transport policy was submitted to a popular vote (referendum). This was the case e.g. for the Alps initiative, Rail 2000, the fund for financing public transport infrastructure projects (the socalled FTP Fund) and also for major railway projects (the GPF).

In sum, the success of the Swiss regional transport reform can be explained. It is based on the proactive stance of public authorities toward the rail system's three major stakeholders.

\section{Conclusion}

The Swiss reform of passenger rail took place within a specific institutional framework and appears to have reached its stated objectives. Although it is said to be modeled on the reforms instigated by the European Commission, detailed analysis shows that the Swiss reform has its particularities (Boodoo, 2002; Finger and Rosa, 2012; Maier-Gyomlay, 2013). For regional transport, the reform was willingly placed under the responsibility of the cantons, based on a "net cost" contract. Although the reform ended the SBB's monopoly in regional transport, one notes a complete absence of competition, as the cantons do not publish calls for tender. Although the reform radically overhauled the organization and management of the incumbent railway operator, the SBB, it did not modify the Swiss railway landscape, made up 
of numerous so-called private domestic operators which have been vertically integrated to complete the SBB network. The results obtained are in accordance with the objectives set by the reform: to increase efficiency and effectiveness in the use of public funds and to strengthen the modal share of the railway, and public transport in general. The stabilization of public compensation paid to the SBB for regional transport, coupled with a strong increase in services offered and in traffic, constitutes an emblematic and enviable success. The increase in the modal share of rail owes much to the increase in services offered and in their heightened quality. With Rail 2000 , the trains serve more stations, the schedules are aligned and easier to read, travel times have been reduced, the price of subscriptions kept low and intermodality, already very high, further strengthened. After the authorities and the taxpayers, those who use public transport, particularly trains, are the reform's second "winners".

The results obtained are due, for the most part, to the nature of public governance and its impact on the behavior of all stakeholders. In Switzerland, the public authorities clearly chose to improve the effectiveness and efficiency of the rail system by imposing an original form of governance, rather than by submitting to the forces of competition (Finger and Genoud, 2004). Swiss railway reform imposed "performance constraints" on the incumbent railway operator and, more generally, on all public transport companies. Regional passenger traffic is an exemplary illustration of this type of governance: a total lack of competition on and for the market and yet significant gains in efficiency and effectiveness. However, competition is not entirely absent. The coexistence, alongside the SBB, of many other railway companies allows the authorities (FOT) to benchmark and maintain healthy rivalry between the networks. Thus competition by comparison (Shleifer, 1985; Auriol, 2000; Bouf and Lévêque, 2006) is possible in Switzerland.

One must however examine the sustainability of such a model. The constant search for savings and productivity gains has led to criticism and has already encountered certain limits. Some (Nahrath et al., 2008) fear the effects on the sustainability of the rail system, both from a technical point of view (with disinvestment limiting future improvements in traffic and operation robustness), and from a social one (various saving schemes complicating access to services for some categories of customers). The sustained increase in traffic, which has exceeded expectations, within a network where use levels were already very high, means substantial infrastructure maintenance requirements, which are difficult to meet in a context where public funds are scarce (Leuenberg, 2010). The slight increase in public contributions for regional transport also illustrates the limits of the quest for the efficient use of public funds (Table 1, above).

Swiss rail excellence comes with costs which must not be forgotten: financial costs, political costs, and even managerial costs. First and foremost, rail excellence involves considerable financial effort on the part of taxpayers (Masse, 1991), unparalleled elsewhere (Prud'homme, 2009). Quality railway production requires continuous high levels of investment (ECMT, 1999). Although Switzerland has designed intelligent and sustainable financing mechanisms, based on dedicated resources (NERA, 2004), the current context of scarce public money and sluggish economic growth ensure that financing will remain a true challenge, in Switzerland as elsewhere (Leuenberger, 2010). As for political costs: the quest for rail excellence entails constant and sustained support from public authorities in their role of "large assembler" for the public transport system. In Switzerland, the public authority (FOT) defines and implements transport policy based on a close coordination of all modalities and on long term programming of objectives and expected actions. Lastly, managerial costs: public authorities 
as the SBB's unique shareholder, fully play their part of owner both by assigning demanding strategic objectives, shared by all and under contract, and by accepting the price.

All in all, Swiss railway reform deserves more consideration and further studies in order to better understand its successes, limits, and the lessons to be drawn for other European policy makers. A careful examination of its specificities would probably show that it would not be an easy model to replicate in other national contexts.

\section{Bibliography}

Auriol E., 2000. La concurrence par comparaison: un point de vue normatif. Revue Economique, 51, 621-634.

Blumenthal P., 1998. Trafic voyageurs régional (TRV): évolution et perspectives aux CFF. Rail international, 29/4, 2-7.

Boodoo A., 2002. An International Comparison of Railway Organizational and Planning Frameworks. Proceedings of the Universities' Transport Studies Group Conference, vol. 3, Napier University, Edinburgh.

Bouf D., Lévèque J., 2006. Yardstick competition for infrastructure services. In: ECMT, OECD, Transport services: the limits of (de)regulation, OECD Press, Paris, pp. 63-108.

Bovy P.H., 1992. Le modèle ferroviaire suisse: un modèle à suivre?. Les Cahiers scientifiques du transport, 25, 47-66.

Bovy P.H., 1994. L'expérience suisse de l'intermodalité. Transports, 365, 187-194.

Carron N., 2004. La politique ferroviaire dans le cadre de la politique générale des transports en Suisse. Rail International, 17-29.

CER, 2011. New Reforming Railways - Learning from Experience. Brussels.

CER, 2012. EVES-Rail - Economic effects of Vertical Separation In the railway sector. Full report. Amsterdam.

Crozet Y., Desmaris C., 2011. Le transport ferroviaire régional de voyageurs: un processus collectif d'apprentissage, Recherche Transports Sécurité, 27/3, 143-162.

Crozet Y., Nash C., Preston J., 2012. Beyond the quiet life of a natural monopoly: Regulatory challenges ahead for Europe's rail sector. Policy paper. CERRE. Brussels.

Desmaris C., 2010. Le transport ferroviaire régional de voyageurs en France: à la lumière de la théorie néo-institutionnaliste et des comptes de surplus, Thèse de doctorat de sciences économiques, Université de Lyon.

EC, Directive 91/440 of the Council of 29 July 1991 on the development of the Community's railways, OJ L 23, 24/08/1991.

EC, COM2013/25. The fourth railway package - completing the single European railway area to foster European competitiveness and growth, Brussels.

ECMT, 1998. Rail restructuring in Europe. OECD Press, Paris.

ECMT, 1999. Investment in transport infrastructure 1985-1995. OECD Press, Paris.

ECMT 2007. Railway accounts for effective regulation, OECD Press, Paris.

Federal Law of 20 December 1957 relating to railways (LCdF). RS 742.101

Federal Law of 24 March 1995 relating to railways. RS 742.101.

Federal Law of 20 March 1998 on federal railway (LCdF). RS 742.31.

Federal Law of 20 March 2009 relating to passenger transport (LTV). RS 754.1. 
Finger M., Genoud C., 2004. Concurrence dans les chemins de fer: une chimère?, Lausanne, EPFL, MIR.

Finger M., Rosa A. et al., 2012. Governance of competition in the Swiss and European railway sector, Final report for SBB, Florence School of Regulation.

Friebel G., Ivaldi M., Vibes C., 2003. Railway (de) regulation: a European efficiency comparison. IDEI report no 3 on passenger rail transport, University of Toulouse.

Genoud C., 2000. La régionalisation des transports publics: implications de la nouvelle loi sur les chemins de fer à l'exemple des cantons de Berne, Zurich, Neuchâtel et Jura. Lausanne, Cahier 188, IDHEAP.

Keseljevic C., Meillasson S., 2001. Le ferroviaire en Suisse. Rail, 84, 14-22.

Kessides I. N., Willig R. D., 1995. Restructuring Regulation of the Rail Industry for the Public Interest, Washington DC, World Bank.

Leuenberger M., 2010. "L'âme ferroviaire de la Suisse", Conférence des cadres des CFF du 24 juin, DETEC, Bâle.

Litra, 2008. Le point sur la politique suisse des transports. Berne.

Litra, 2011a. Financement de l'exploitation et entretien du réseau ferroviaire. DOKU, 21 mars, Berne.

Litra, 2011b, La statistique ferroviaire 2010 de l'UIC, DOKU, 03 août, Berne.

Litra, 2012. Les transports en chiffres, Edition 2012. Berne.

Maier-Gyomlay J., 2013. Learning lessons from Switzerland - A BLS perspective. Railway Gazette International, January, 36-40.

Masse J.-P., 1991. Spécial Suisse. Le paradis a un prix. Vie du Rail, 2325, 4-20.

Meillasson S., 2002.100 ans de CFF. Rail, 95, pp. 16-33

Meier B., Meyer A., 2011. Switzerland, pp. 127-135 in CER (2011), New Reforming Railways - Learning from Experience. Eurailpress, Brussels / Hamburg.

Nahrath S., Rieder M. et al., 2008. Les impacts de la régionalisation et de la libéralisation sur la durabilité du secteur ferroviaire en Suisse. Flux, 72/73, 49-64.

Nash C., 2011. Developments in European railway policy. Network Industries Quarterly, 13/1, 11-13.

NERA, 2004. Study of the Financing and Public Budget Contributions to Railways, Final report for the European Commission, January, London.

OECD, 2006. Regulatory reform in Switzerland - Regulatory authorities for air transport, railways, telecommunications and postal services. Paris.

OFS, 2004. Le Compte ferroviaire en Suisse 2003, OFS, Berne.

OFS, 2011. Le Compte ferroviaire en Suisse 2010, OFS, Berne.

OFS, 2012. La mobilité en Suisse - Résultats du micro-recensement mobilité et transports 2010, Neuchâtel.

Ordinance of 18 December 1995 relating to the indemnities, loans and financial aids granted according to the LCdF (OIPAF). RS 742.101.1.

Ordinance of 11 November 2009 relating to the indemnities of regional passenger traffic (OITRV). RS 745.16.

Peschelt, F., 2010. Governance in Railway Networks, Paper presented at the European Transport Conference, AER. 
Prud'homme R., 2009. Du modèle ferroviaire suisse. Transports, 457, 304-306.

SBB, 2005. Report on the Group's financial position SBB in 2004, SBB, Bern.

SBB, 2009. Report on the Group's financial position SBB in 2008, SBB, Bern.

SBB, 2012a. SBB: Facts and figures 2011. SBB, Bern.

SBB, 2012b. SBB: Annual and sustainability report 2011. SBB, Bern.

Shleifer A., 1985. A theory of yardstick competition. The Rand Journal of Economics, 16/3, 319-327.

Torrego C., Graffagnino T., 2012. Le système cadencé suisse: caractéristiques essentielles et impacts en matière de production, Revue Générale des Chemins de Fer, 219, septembre, 36-50.

UIC, 2010. Historical statistics of railways 1970-2009, Paris.

UIC, 2011. International Statistics Railways 2010, Paris.

UTP, 2008. Les transports publics en Suisse, Berne.

Van de Velde D., 1999. Switzerland. In D. van de Velde (ed.), Changing Trains. Railway reform and the role of competition: The experience of six countries. Aldershot/Brookfield, USA, Ashgate.

Weibel B., 2005. Switzerland, in CER, Reforming Europe's Railways - An assessment of progress. Eurailpress, Brussels / Hambourg.

Weibel B., 2012. Le projet Rail 2000, Revue Générale des Chemins de Fer, 219, 52-54. 